\section{Utilization of Agroindustry Wastewater as Growth Medium for Microalgae based Bioenergy Feedstock in Indonesia (an Overview)}

\section{M.M. Azimatun Nur ${ }^{*}$ H. Hadiyanto}

Center of Biomass and Renewable Energy, Chemical Engineering Diponegoro University Jl Prof Soedarto, SH. Tembalang 50275, Semarang, Indonesia.

Received: March 14, 2013/ Accepted: April 25, 2013

\begin{abstract}
Indonesia has been well-known as an agricultural country for a long time. Several leading agroindustry products are increasing due to demand from world consumption. On other hand, wastewater production has increased in parallel with agroindustry production. It is predicted that wastewater will threaten the environment due to high COD and BOD content. A second problem in Indonesia is the energy crisis, due to petroleum depletion, and energy demand increase. A feasible technology is needed to solve both these problems. Almost all agroindustry wastewater contains nitrogen, phosphorus, and several micronutrients. It is seen as a potential medium for microalgae growth. Due to the tropical climate, light, and other factors, it is predicted that microalgae cultivated in agroindustry wastewater could be a potential biomass for bioenergy feedstock and a good phytoremediator to lower toxic matter in wastewater.
\end{abstract}

Keywords: Indonesia wastewater agroindustry, biomass microalgae, bioenergy feedstock

\section{Introduction}

Currently, Indonesia is one of the leading agroindustry producers in the world. The major food crops, ranked by area harvested quantity, are rice, corn, cassava, soybeans and peanuts. Indonesia is also one of the world's largest producers and exporters of tree crops such as palm oil, rubber, copra, palm kernels, coffee, cocoa and spices [1]. This agricultural production has the potential to generate wastewater pollutants and greenhouse gases.

On other hand, Indonesia is in an energy crisis. The demand of energy has constantly increased through the years (Figure 1). Simultaneously, decreasing discoveries of new fossil fuel sources, minimal renewable energy feedstocks, and increasing human population are exacerbating the crisis.

One of most promising technologies to be implemented in Indonesia is microalgae-technology-based biofuel. Indonesia is a tropical archipelago, having a potential to produce microalgae as a blooming biomass source. However, only several microalgae can produce biofuels

Corresponding Author

E-mail: lanaazim.st@gmail.com and utilize agroindustry wastewater as growth medium [3]. Finally, in this process, the COD, BOD, and other pollutants will be removed, and the biomass product from microalgae is used as feedstock of bioenergy.

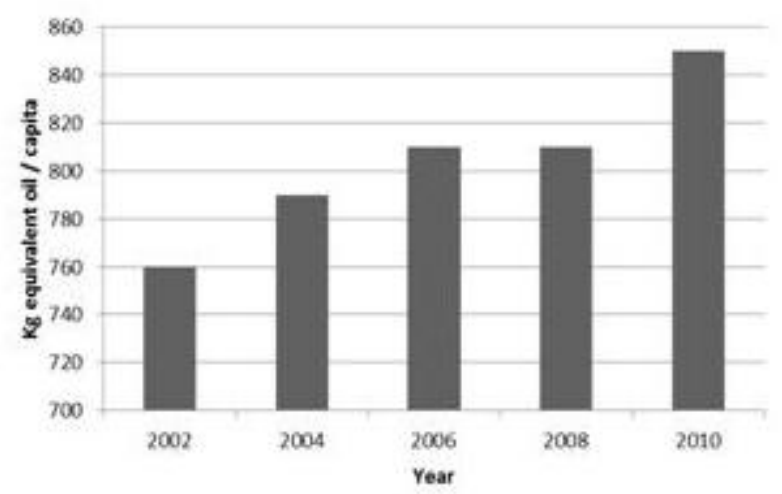

Figure 1 Indonesian energy consumption equivalent per capita [2]

\section{Microalgae As Biofuel Feedstock}

Researchers are interested to microalgae as biofuel feedstock due to the potential for high production all year round regardless of the season, rapid production, nutrient and heavy metal removal from wastewater, and the utilization of $\mathrm{CO}_{2}$ in large quantities [3].

Microalgae appear to represent the only currently renewable way to generate biofuels [4]. Compared to other oil sources, it has higher lipid productivity than other crops (Figure 2). Microalgae biofuels are also likely to have a much lower impact on the environment and do not encroach on the world's food supply as compared with conventional biofuel-producing crops. When compared to plant biofuels, microalgal biomass has a high caloric value, low viscosity and low density - properties that make microalgae more suitable for biofuel than lignocellulosic materials [5].

Chisti [4] reported that production cost per kilogram of microalgal biomass is $\$ 2.95$ and $\$ 3.80$ for photobioreactors and raceways, respectively. These estimates assume that carbon dioxide is not included as a cost. However by using wastewater nutrient, costs of production could be lowered.

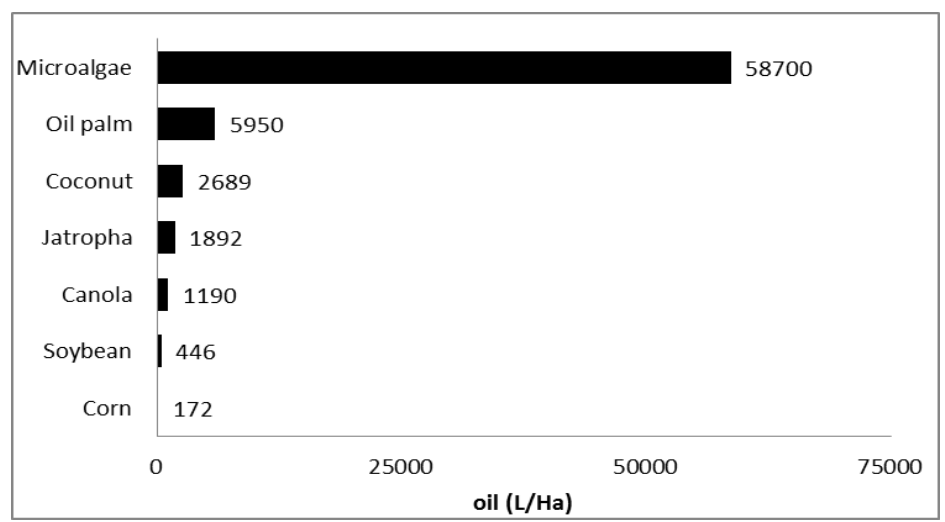

Figure 2 Comparison of potential source of biodiesel. Microalgae contains $30 \%$ oil $[4]$

\subsection{Biomass Conversion}

Biomass conversion from microalgae can be applied to biodiesel products, but also bioethanol, biohydrogen, methane, or even for 
electricity production [6]. A schematic of microalgae biomass conversion is shown in Figure 2. However, in the international market, the most technically feasible and commercialized alternative renewable fuel sources are biodiesel and bioethanol [7].

Several researchers found that oil from microalgae could be converted to biodiesel, by using supercritical and microwave methods [8], ultrasound methods [9, 10], and direct transesterification (in situ) [11].The last method is one of the most promising technologies due to the simple process and lower energy consumption to produce biodiesel from microalgae $[8,12$, 13]. By using In situ transesterification, energy consumption could be lowered due to bypassing lipid extraction. Dry biomass is used in the transesterification process to produce biodiesel using solvents and a catalyst.

Moreover, researchers are also interested in the feasibility of biodiesel conversion of microalgae biofuel cultivated in wastewater. Penglin [14] reported that direct transesterification is feasible applied in microalgae cultivated in rice straw wastewater. $\mathrm{Wu}$ [15] investigated the feasibility of biodiesel production by microalgae using industrial wastewater and conclude that microalgae could remove ammonium and accumulate $18,4 \%$ lipid, and that the composition of this lipid is suitable to produce biodiesel.

Several factors are also considered to affect lipids in microalgae. Widjaja et al. concludes that several factors increase lipids in Chlorellavulgaris such $\mathrm{CO}_{2}$ concentration, nitrogen depletion, harvesting time, and extraction method [16]. Moreover, the specific strain inoculum also plays an important role to produce high microalgae-based biofuel.

In fact, assuming that the biomass contains $30 \%$ oil by weight, the cost of biomass for providing a liter of oil would be something like $\$ 1.40$ and $\$ 1.81$ for photobioreactors and raceways, respectively [4].

\subsection{Enhancement of Economic Feasibility of Biofuel Production from Microalgae}

Feasibility and sustainability of production of biomass from microalgae have to be placed in the process to push cost value and meet a reasonable price. Several factors affecting the economics of the process are the biorefinery system integration, advanced photobioreactor design, and conversion technology system.
Biorefineries for microalgae could be likened to a petroleum refinery. A biorefinery uses every component of the raw material to produce useable products and lower the overall cost production [4]. Microalgae not only produce biofuel but can also provide bioprotein and several other valuable products. The economic feasibility of microalgal biofuel production should be significantly enhanced by a high-value co-product $[17,18]$. For example, microalgae based protein for animal feed is around $\$ 10-\$ 20 / \mathrm{kg}$, and pigments from microalgae such phycocyanin or chlorophy are around $\$ 700-\$ 1000 /$ liter in Indonesian market prices. Products such glycerol are also potential by-products to cover overall biofuel costs.

The specific bioreactor is important in microalgae cultivation. Several methods that meet the cost and production rates also have to be considered. A number of authors have discussed the difference between open and closed systems [4][19][20].

Hybrid systems are a new alternative for cultivating microalgae [7]. Combinations of both systems are probably the most logical choice for cost effective cultivation of high yielding strains for biofuels.

Biomass conversion systems also influence the cost efficiency of production. Traditional methods of microalgae technology use a sequence of harvesting, extracting, and converting to biofuel. However, to push the market in renewable fuel/energy, the Indonesian government has lowered or eliminated the taxes for fuel grade bioethanol and biodiesel especially.

\section{Indonesian Agroindustry}

Indonesia is an agricultural country which leads in several agro product exports. Three major export agroindustry products are derivative palm oil, rubber and cacao.

\subsection{Crude Palm Oil}

Palm is a leading crop product in Indonesia. In the last ten years, CPO production increased significantly by $13.4 \%$ [21]. Indonesia and Malaysia shared almost $80 \%$ of total CPO demand in the world.

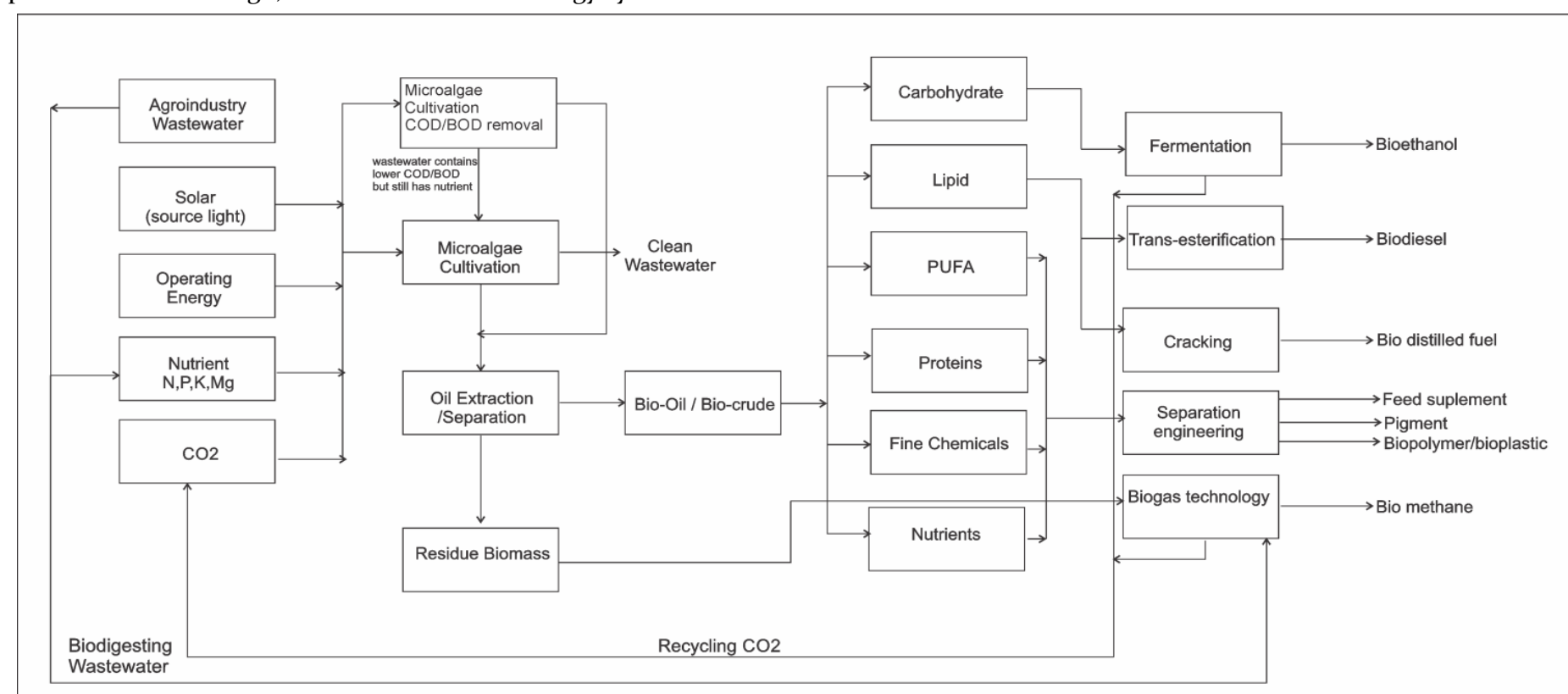

Figure 3 Integrated Biorefinery for Microalgae Wastewater Treatment. Modified from Singh and Gu [17] 
Table 1 CPO Market share (In 2010) [21]

\begin{tabular}{llcc}
\hline No & Country & Production (ton) & Market share \\
\hline 1 & Indonesia & $23.2 \times 10^{6}$ & $43.60 \%$ \\
2 & Malaysia & $19.3 \times 10^{6}$ & $36.20 \%$ \\
3 & Other Country & $10.7 \times 10^{6}$ & $20.20 \%$ \\
\hline
\end{tabular}

However, along with CPO production, wastes and pollution generated from the process has increased.

\subsubsection{POME}

Palm oil mill effluent (POME) is wastewater generated from CPO processing. It is rich in nutrients, a dark color, and acidic in its $\mathrm{pH}$. Indriyati [22] reported that processing a fruit fresh bunch (FFB) of palm produces waste water pollutants up to $66 \% \mathrm{v} / \mathrm{w}$.

Releasing un-treated POME directly to the surroundings will cause serious pollution problems in the environment due to high COD and BOD content and could produce greenhouse gases.

Instead, POME can be treated efficiently using available wastewater treatment technologies in order to meet the standard discharge regulations for wastewater.

Table 2 POME Characteristic [23]

\begin{tabular}{|c|c|}
\hline Parameter & Raw POME \\
\hline $\mathrm{pH}$ & 4.7 \\
\hline BOD & $62,500-69,215$ \\
\hline COD & $95,465-112,023$ \\
\hline Total Solid & $68,854-75,327$ \\
\hline Suspended Solid & $44,680-47,140$ \\
\hline Total Nitrogen & $1,305^{-1,493}$ \\
\hline
\end{tabular}

Note: All in ppm except $\mathrm{pH}$.

\subsubsection{POME as Microalgae Medium}

Several researchers investigated the potential of POME as a microlgae medium. Habib et al [24], reported that POME is a potential medium for microalgae growth. Meanwhile Putri et al.[25] recorded several biofuel microalgae able to be cultivated in diluted POME (25oppm COD).

Among them, Chlorella sorokiniana was the highest in terms of specific growth rate and biomass productivity, when compared to the other species (Table 3). Hadiyanto and Nur [26] also reported preliminary investigation of Chlorella sp in $50 \% \mathrm{v} / \mathrm{v}$ digested POME by modifying the carbon, nitrogen, and phosphorus ratio. The resulst showed that 50\% digested POME and 1gr/l urea addition gave biomass of Chlorella sp. up to $58.4 \mathrm{mg} / \mathrm{l}$ in 16 days cultivation.

Table 3 Microalgae in POME Medium [25]

\begin{tabular}{lcc}
\hline Microalgae Strain & $\begin{array}{c}\text { Biomass Productivity } \\
(\mathbf{m g} / \mathbf{l} / \text { day) }\end{array}$ & Lipid (\%) \\
\hline Chlorella vulgaris & 5.9 & 21.34 \\
Chlorella pyrenoidosa & 2.9 & 21.51 \\
Chlorella sorokiniana & 8.0 & 28.27 \\
Botryococcus sudeticus & 5.3 & 30.83 \\
Tetraselmis sp & 4.0 & 25.69 \\
\hline
\end{tabular}

One problem of POME as medium for microalgae is the high COD content, dark color of tannic acid, and high impurity. This problem could be solved by using an integrated process. Untreated POME can be processed by using anaerobic methods to lower $\mathrm{COD}$ and $\mathrm{BOD}$ content and generate methane and $\mathrm{CO}_{2}$; meanwhile the effluent containing residual amounts of nutrient could be used as a medium for microalgae. Habib et al. also reported that Chlorella vulgaris cultivated in $10 \%$ digested-POME contains $18.3 \%$ crude lipid, while the lipid decreases to $16.8 \%$ when cultivated in 20\% digested-POME. However, the COD and related content of digested POME has changed after beomg used as medium for Chlorella vulgaris. [25]

Table 4 POME digested before and after use as medium [24]

\begin{tabular}{lll} 
Parameter $^{*}$ & Before & After $^{* *}$ \\
\hline $\mathrm{pH}$ & 6.8 & 7.2 \\
$\mathrm{Dis} \mathrm{O} 2$ & 3.6 & 3.5 \\
$\mathrm{COD}$ & 4245.5 & 220 \\
$\mathrm{TS}$ & 1926 & 115.4 \\
$\mathrm{TSS}$ & 959.7 & 42.5 \\
T.Nitrogen & 228 & 17.6 \\
Orthophosphate & 34.2 & 2.8 \\
\hline
\end{tabular}

Notes: *all parameter in ppm except $\mathrm{pH}$

** experiment in aerated medium

Microalgae grew slowly in higher concentrations of digested POME due to inadequate light. The specific growth rate affecting COD and BOD removal is therefore low in POME medium.

\subsection{Rubber}

Rubber is the second largest agroindustry product in Indonesia, and also ranked as $2^{\text {nd }}$ largest producer in the world in 2010 with market shared up to $28 \%$. In 2009 , Indonesia produced 2.4 million tons of rubber, Thailand 3.1 million tons, and Malaysia 951 thousand tons [21]. However, Indonesia has the largest area of rubber plantations in the world, with up to 3.40 million hectares, followed by Thailand and Malaysia.

During rubber production, $25 \% \mathrm{v} / \mathrm{w}$ wastewater pollutant was generated as rubber mill effluent [27]. The effluent is usually treated by traditional aerobic-anaerobic facultative methods. However these methods are only effective to remove COD and BOD content.

\subsubsection{Rubber Mill Effluent}

Rubber Mill effluent (RME) consists of latex washings and a serum containing proteins, sugars and lipids as well as inorganic and organic salts. The high level of ammonium and other plant nutrients makes it a good medium for algal growth.

\subsubsection{RME as Microalgae Medium}

There are few reports about microalgae cultivated in RME as biofuel feedstock but several researchers have investigated microalgae (i.e. Spirulina platensis, Chlorella vulgaris, and several cyanobacteria) in RME and it is reported that RME is a potential medium for microalgae.

Tri-panji and Suharyanto [28] investigated growth and carotenoid production of Spirulina platensis cultivated in medium enriched latex concentrate rubber effluent (LCRE) and concluded that the cost of synthetic medium could be lowered by adding the LCRE at $5 \% \mathrm{v} / \mathrm{v}$.

Senthil et al. [29] reported that rubber mill effluent significantly influencing the biochemical constituents of cyanobacteria both qualitatively and quantitatively, but that reported increases in amino acids and unsaturated fatty acids should be investigated for further research.

Table 5 RME Characteristic from Ribbed Smoked Sheet [27]

\begin{tabular}{ll} 
Parameter & Means Value \\
\hline $\mathrm{pH}$ & $5 \pm 1$ \\
$\mathrm{COD}$ & $4000 \pm 1000$ \\
$\mathrm{BOD}$ & $2500 \pm 200$ \\
Total Nitrogen & $300 \pm 100$ \\
$\mathrm{NH}_{3}-\mathrm{N}$ & $200 \pm 100$ \\
$\mathrm{NO}_{3}-\mathrm{N}$ & $6 \pm 2$ \\
$\mathrm{PO} 4-\mathrm{P}$ & $30 \pm 10$ \\
\hline
\end{tabular}

Note: *All parameter in ppm except $\mathrm{pH}$ 
Habib et al.[30] also recorded an increase of biomass, protein and lipids from tropical green algae, Ankistrodesmus convolutus, cultivated in diluted latex concentrate rubber effluent (LCRE), and in standard rubber mill effluent (RME). Lipid was recorded significantly higher than in the control medium - $15.75 \%$ and $15.15 \%$, respectively.

\subsection{Cocoa}

Cocoa is the third leading agroindustry product from Indonesia. In 2009, Indonesia ranked $2^{\text {nd }}$ in the world market, following Ghana. Increasing production by up to $7.60 \%$ (2000-2010) [21], in 2009, Indonesia produced 830,790 tons.

A fine cocoa product is processed by fermentation methods to lower tannic acid. Along with demand for fermented cacao, wastewater pollutants generated from the fermentation process have also increased.

\subsubsection{Fermented Cocoa Bean Mill Effluent}

During the process of cocoa bean sweating, $10 \% \mathrm{v} / \mathrm{w}$ waste water was generated [31]. Fermented cocoa bean mill effluent, also called cocoa sweating effluent (CSE), contains several sugar residues and micro nutrients.

Table 6 Characteristic of cocoa sweating effluent [34]

\begin{tabular}{ll}
\hline Parameter & Value* $^{*}$ \\
\hline TSS & 2,844 \\
VSS & 2,610 \\
pH & 4.41 \\
BOD & 19,100 \\
COD & $109,190.4$ \\
Glucose & 17,510
\end{tabular}

Note: *All in ppm except $\mathrm{pH}$

It is found that investigation of the cocoa effluent in Indonesia is still low. Research has however been done on utilizing the effluent as medium for nata de cocoa [32], and ethanol production [33][34].

\subsubsection{Potential of CSE as Medium of Microalgae}

Few researchers are interested in utilizing CSE as medium for microalgae-based biofuel. However it is predicted to be a potential medium for microalgae due to the glucose value and nutrient content. CSE characteristics are similar to POME medium, the color tends to be dark due to tannins and another chemical compound, and it also has acidic $\mathrm{pH}$.

Heterotrophic microalgae cultivation is one interesting method to increase lipid accumulation in biomass production. It utilizes organic carbon sources, (i.e. glucose, sucrose) without using photosynthetic reactions [35]. Several researchers found that heterotrophic conditions could increase lipid content.

However, in some cases a combination of mixotrophic conditions also influences several microalgae to form higher lipids than autotrophic or heterotrophic condition. When microalgae grow in mixotrophic conditions, they utilize organic carbon sources (i.e. glucose) from wastewater and use light in photosynthetic reactions to form biomass [36].

\section{Integrated Processing of Agroindustry Wastewater for Biogas and Biomass Production}

Almost all agroindustry effluents contain high COD and BOD content. This has potential to generate greenhouse gases and harm the environment. However microalgae grow at a maximum specific growth rate and utilize the agroindustry wastewater by removing nitrogen, phosphorus and micronutrient in low COD and BOD conditions.

This COD and BOD content could be lowered by using anaerobic digesting methods. This process generates methane gas, carbon dioxide and other compounds (Figure 3).

Wastewater influent will be processed in a digestion reactor to produce biogas, then it will be combusted to generate electricity, and the flue gas is utilized as $\mathrm{CO}_{2}$ feedstock for microalgae cultivation in the second cultivation.

Liquid effluent from the biodigester is then used as a medium for microalgae. This effluent usually contains residual nutrient and has lower COD and BOD content.

There are two cultivation systems in this integrated process. In the first cultivation, wild microalgae is used as phytoremediator to lower dye color, heavy metals, COD and BOD content. Biomass produced from this cultivation could be utilized as fertilizer, while residual filtrate is used as growth medium for microalgae based bioenergy in the second step cultivation.

In the second cultivation, microalgae will be cultivated in nitrogen deficient conditions to increase lipid content, and the flue gas will be injected into the medium as a source of carbon. A filtrate could be released in the river and the biomass could be used as feedstock of bioenergy (i.e. biodiesel, bioethanol).

Table 7 Potency of biodiesel dan biomass microalgae from wastewater

\begin{tabular}{llll} 
Source & Wastewater $\left(\mathrm{m}^{3}\right)$ & $\begin{array}{l}\text { Microalgae } \\
\text { Biomass } \\
\text { (ton/year) }\end{array}$ & $\begin{array}{l}\text { Biodiesel } \\
\text { microalgae } \\
(\mathrm{KL} / \text { year })\end{array}$ \\
\hline POME & $1,5312 \times 10^{7}$ & 22049.28 & 6806.511 \\
RME & $6 \times 10^{5}$ & 864 & 266,71 \\
CSE & $8,3 \times 10^{4}$ & 119.52 & 36,89 \\
Total & & 23032,8 & 7110,119 \\
\hline
\end{tabular}

Table 7 describes the potential of biomass and biodiesel production by using Chlorellasorokiniana according to research results in Table 3. It is assumed that microalgae has a harvest cycle of 2 days and reaches $95 \%$ conversion of biodiesel from lipid, and use $100 \%$ total volume of wastewater.

Table 8 Production, consumption, and export of biodiesel in Indonesia $\left(10^{3}\right.$ KiloLiter $)[38]$

\begin{tabular}{llllll} 
Source & $\mathbf{2 0 0 9}$ & $\mathbf{2 0 1 0}$ & $\mathbf{2 0 1 1}$ & $\mathbf{2 0 1 2}$ & $\mathbf{2 0 1 3 ^ { * }}$ \\
\hline Production & 330 & 740 & $1,450.118$ & 1654.2 & 2,200 \\
Export & 204 & 563 & $1,091.306$ & 984.862 & 1,500 \\
Consumption & 60 & 220 & 358.812 & 669.398 & 700 \\
\hline
\end{tabular}

Note: *estimation result

Table 8 is a summary of production, consumption and export of biodiesel in Indonesia. Compared to Table 7 , biodiesel from microalgae cultivated in wastewater could share only about $0,32 \%$ of total production in the country or $1 \%$ of total consumption of biodiesel.

However, other contents of biomass from microalgae such pigments, carbohydrates and proteins, could be explored even further to be converted to other products such bioethanol, fish feed, and fine chemicals (Figure 3 ). 


\section{Future Prospect}

Indonesian agroindustry production is predicted to continue increasing in the future. The potential wastewater associated with it could be a major problem in the process. Microalgae as future biofuel feedstock cultivated in agroindustry wastewater is an interesting technology to be adopted in the country. However a future challenge of finding sustainable and feasible methods to produce microalgae biofuel in agroindustry wastewater is needed to meet rational costs of production.

\section{References}

[1] Ministry of Agriculture, Republic of Indonesia. Agricultural developme nt in Indonesia 1996-200o. Jakarta;2001.

[2] Anonym.2012.Energy use kg of oil equivalent per capita in Indonesia. http://www.tradingeconomics.com/indonesia/energy-use-kg-of-oil-e quivalent-per-capita-wb-data.html. Accessed in 7 March 2013

[3] Singh, Jasvinder and Gu, Sai. Commercialization potential of microalg ae for biofuel production.Renewable and Sustainable Energy Reviews2o 10;14:2596-2610.

[4] Chisti Y. Biodiesel from microalgae. Biotechnol Adv 2007;25:294-306.

[5] Miao X, Wu Q. High yield bio-oil production from fast pyrolysis by $\mathrm{m}$ etabolic controlling of Chlorella protothecoides. J Biotechnol 2004;110: $85-93$.

[6] Wang B, Li Wu N,Lan CQ. $\mathrm{CO}_{2}$ bio-mitigation using microalgae. Appl Microbiol Biotechnol2008;79:707-718.

[7] Gouveia L.Microalgae as Feedstock for Biofuels, 1st ed., New York:Spri nger;2011.

[8] Patil PD, Veera GG, Aravind M, Cooke P, Stuart MM, N Nagamany, La mmers P, Shuguang D. Optimization of microwave-assisted transester ification of dry algal biomass using response surface methodology. Bio resour. Technol 2011; 102:1399-1405.

[9] Babajide O, Petrik L, Amigun B, Ameer F. Low-CostFeedstock Conver sion to Biodiesel via Ultrasound Technology. Energies 2009;3:1691-1703

[10] Ehimen EA, Shun Z, Carrington GC.Use of ultrasound and co-solvents to improve the in-situ transesterification of microalgae biomass.Proc edia Environmental Sciences 2012; 15:47 - 55.

[11] Lieve MLL, Quinn M, Stefanie VW, David WT, Edward JW. Accurate and reliable quantification of total microalgal fuel potential as fatty ac id methyl esters by in situ transesterification. Anal Bioanal Chem 2012; 403:167-178.

[12] Ehimen EA, Sun Zhifa, Carrington CG. Variables affecting thein situ tr ansesterification of microalgae lipids. Fuel 2010; 89:677-684.

[13] Xu Ling, Chen Guo, Feng Wang, Zheng Sen, Liu CZ. A simple and rapi $\mathrm{d}$ harvesting method for microalgae by in situ magnetic separation. $B i$ oresour Technol 2011;102:10047-10051.

[14] Penglin Li, Miao X, Li Rongxiu, Jianjiang Zhong. A simple and rapid h arvesting method for microalgae by in situ magnetic separation. J. Bi omedicine \& Biotechnol 2011: 1-8.

[15] Wu LF, Chen PC, Huang AP, Lee CM. The feasibility of biodiesel prod uction by microalgae using industrial wastewater. Bioresour Technol 2012; 113:14-18.

[16] Singh J, Gu S.Commercialization potential of microalgae for biofuels $\mathrm{p}$ roduction. Renew and Sust Energ Rev 2010;14:2596-2610.

[17] Widjaja A, Chang-Chien C, Ju Y. Study of increasing lipid production $\mathrm{f}$ rom fresh water microalgae Chlorella vulgaris. J Taiwan Institute of $\mathrm{Ch}$ emical Engineers 2009;40:13-20.

[18] Li Y, Horsman M, Wu N, Lan CQ, Dubois-Calero N. Biofuels from Mic roalgae.Biotechnol. Prog2008;24:815-820.

[19] Carvalho AP, Meireles LA, Malcata FX. Microalgal reactors: a review o f enclosed system designs and performances. Biotechnol Prog 2006;22: 1490-1506.

[2o] Harun R, Singh M, Forde GM, Danquah MK. Bioprocess engineering o f microalgae to produce a variety of consumer products. Renew Sust $E$ nerg Rev 2010;14:1037-1047.

[21] Ministry of Industrial Republic Indonesia, Outlook Industry 2012: Stra tegi Percepatan dan Perluasan Agroindustry. Jakarta;2011.

[22] Indriyati, Potensi Limbah Industri Kelapa Sawit di Indonesia.M.Tek.Li $n g$ 2008;4(1):93-103.

[23] Choorit W, Wisarnwan P.Effect of temperature on the anaerobic diges tion of palm oil mill effluent. Electr. J. Biotechnol 2007; 1o(3):376-385.
[24] Habib MAB, Yusoff FM, Phang SM, Kamarudin MS, Mohamed S. Nutr itional Values of Molina micrura Fed on Chlorella vulgaris Grown in D igested Palm Oil Mill Effluent. Asian Fisheries Science2003;16:107-119.

[25] Putri EV,Din MFM, Ahmed Z, Jamaluddin H, Chelliapan S. Investigati on of Microalgae for High Lipid Content using Palm Oil Mill Effluent (Pome) as Carbon Source. IPCBEE 2011; 12:85-89.

[26] Hadiyanto, Nur MMA. Potential of Palm Oil Mill Effluent (POME) as Medium Growth of Chlorella sp for Bioenergy Production. Int J Env an d Bioenerg2012;3(2):67-74

[27] Dirjen Perkebunan.Study of Pollution Control Requirements for Existin $g$ PTP Palm Oil and Rubber Factories. Final Report. Vol. 1;1991.

[28] Utomo TP, Romli M, Fauzi AM, IsmayanaA. Kajian proses penyisihan nutrien dari limbah cair pabrik karet menggunakan reaktor tiga tahap . Manajemen dan Kualitas Lingkungan 2001;1 (4):31-39.

[29] Tri-Panji , Suharyanto. Optimization media from low-cost nutrient so urces for growing Spirulina platensis and carotenoid production. Men ara Perkebunan 2001; 69(1):18-28

[3o] Senthil P, Jeyachandren S, Manobaran C, Vijayakumar S. Impact of ru bber industry effluent on the amino acid and fatty acid content of cya nobacteria. Eur J Exp Bio 2012;2 (1):266-269.

[31] Habib MAB, Yusoff FM, Phang SM, Kamarudin MS, Mohamed S. Gro wth and Nutritional Value of a Tropical Green Alga, Ankistrodesmus c onvolutus Corda, in Agro-industrial Effluents. PertanikaJ. Trop. Agric. Sci.2004 27(2):79-89.

[32] Buamah R, Dzogbefia VP, Oldham JH. Pure yeast culturefermentation of cocoa (Theobroma cacao $L$ ): effect on yield of sweatings and cocoa bean qual. World J Microbiol Biotechnol 1997;13(4):457-462.

[33] Pratiwi E. Karakteristik nata dari pulp kakao mulia (Theobroma cacao $L$ ) dengan penambahan berbagai konsentrasi sukrosa. Jurnal teknologi pangan dan hasil pertanian 5.(2):81-85.

[34] Syafila M, Handajani M, Prayascitra A. The Effect of Nitrogen Gas Flus hing on Intermediate Products Formation in Acidogenic Stage of Ana erobic Process of Cocoa Sweatings. ITB J. Eng. Sci.2010;42(2):129-136

[35] Darnoko Desrizal, Hartoto L. Continous ethanol fermentation from c ocoa pulp liquid waste using imobilized yeast cells.PAU Biotech IPB19 91:17-191.

[36] Heredia-Arroyo T, Wei W, Ruan R, Hu B. Mixotrophic cultivation of Chlorella vulgaris and its potential application for the oil accumulatio $\mathrm{n}$ from non-sugar materials. Biomass and bioenergy 2011; 35: 2245-2253

[37] Cheirsilp B, Totpee S. Enhanced growth and lipid production of micro algae under mixotrophic culture condition: Effect of light intensity, gl ucose concentration and fed-batch cultivation. Bioresource Technolog y 2012;110:510-516.

[38] Sawit Indonesia. Saatnya Pasar Biodiesel Tumbuh. http://sawit-indon esia.com/index.php/hot-issue/208-saatnya-pasar-biodiesel-tumbuh. accessed 23 April 2013 